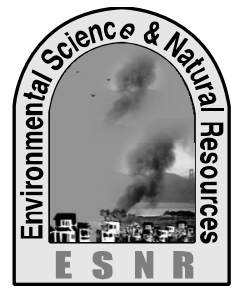

\title{
Comparative Study among Composite Breads Incorporated with Full Fatted and Defatted Rice Bran
}

\author{
R. Begum*, S. Ahmed, M. L. Hakim and J. Sen \\ Department of Food Technology and Nutritional Science, \\ Mawlana Bhashani Science and Technology University, Santosh, Tangail-1902, Bangladesh \\ *Corresponding author: rokeya15@yahoo.com
}

\begin{abstract}
Rice bran, a milling byproduct of rice is rich in nutrients especially high in fiber and protein in comparison with white wheat flour-which is predominantly used for bread production. Inclusion of rice bran with wheat flour was expected to induce nutritional value of bread positively. Two form of rice bran sample both full fatted and defatted were incorporated with wheat flour in a proportion of $0 \%, 5 \%, 10 \%$ and $15 \%$ respectively to develop composite bread. Physical, chemical, and sensory evaluation was carried out to determine the quality of different composite breads. Bread weight didnâ differ statistically though there was a marginal declination of volume for bread with the increase of the percentage of rice bran. The percentage of protein and fiber was increased rationally as expected. A level of $10 \%$ rice bran added to bread was regarded to yield good sensory quality.
\end{abstract}

Key words: Composite bread, Free fatty acid, Functional food, Rice bran, Sensory attributes

\section{Introduction}

In recent years, there has been a global trend towards the use of natural substances present in foods as a source of functional ingredients (Kim, 2005). Efficient utilization of food products, food wastes and unconventional food sources for human consumption would result in increased nutritional value of products made from available resources (Houston, 1972). Rice bran is an inexpensive, underutilized milling by-product of rough rice. The yield of husk-bran and milled rice from $100 \mathrm{~kg}$ paddy are $22.8 \mathrm{~kg}$ and $73 \mathrm{~kg}$, respectively. It contains $12-$ 22 per cent oil, $11-17 \%$ protein, 6-14\% fiber, $10-15$ per cent moisture and $8-17 \%$ ash. It is rich in vitamins including vitamin $\mathrm{E}$, thiamin, niacin and minerals like aluminum, calcium, chlorine, iron, magnesium, manganese, phosphorus, potassium, sodium and zinc (Quereshi et al., 2000).

Rice bran is used for the enrichment of foods, due to its high dietary fiber content. Since the middle of the 1970s, the role of dietary fiber in health and nutrition has stimulated a wide range of research activities which caught public attention. Accumulating evidence favors the view that increased intake of dietary fiber can have beneficial effects against diseases, such as cardiovascular diseases, gastrointestinal disease, decreasing blood cholesterol, diabetes diverticulitis, and colon cancer. In view of the therapeutic potential of dietary fiber, more fiber incorporated food products are being developed. Addition of dietary fiber to a wide range of products will contribute to the development of value-added foods or functional foods that currently are in high demand ( $\mathrm{Hu}$ et al., 2009). Along with that rice bran is considered a good source of hypoallergenic proteins; therefore, rice bran protein may serve as a suitable ingredient for infant food formulations (Wang et al., 1999).

Rice bran also plays an important role in decreasing cholesterol and controlling of blood glucose level. The rice bran contains an approximate insoluble versus soluble fiber ratio of 5 to 1 , which exhibits a high digestive tolerance that occurs along the whole digestive tract with no excessive fermentation in the large intestine. Processed rice bran contains astounding quality 
of synbiotics, tocols, oryzanols, polyphenols, sitosterol, phytosterols and is packed with full of omega-3 and omega-6 fatty acids. Healthy complex carbohydrates found in processed rice bran have ñow glycemic indexò which means they do not cause spikes in blood glucose (Sayre et al., 2007).

Rice bran, a "little known" food is highly nutritious and delivers a powerhouse of health supporting nutrients which is either thrown away or used for low-level animal feed. Even though rice bran is a produced in large quantity in Bangladesh yearly, its application in foods is very limited, as well as its application of such ingredient to food products have not been widely studied and published. Therefore, the purpose of this study is to determine the applicability of rice bran in bakery products.

\section{Materials and Methods}

\section{Collection of sample}

Rice (variety: BRRI dhan-29) bran sample was collected from Haji Auto Rice Mills (Pvt.) Ltd, Tangail, Bangladesh. Wheat flour and remaining ingredients for product development were purchased from the local market, Tangail. All reagents (analytical) and standards were from Merck (Merck KGaA, Darmstadt, Germany) and Sigma-Aldrich (Sigma-Aldrich Tokyo, Japan).

\section{Sample preparation}

The selected parboiled rice bran (full fatted) for this study was the milling byproduct of the parboiled rice (rice variety: BRRI dhan-29). The full fatted parboiled rice bran was sieved on a 100 mesh screen to remove impurities. This parboiled rice bran was then defatted according to the method of Wang et al. (1999). Then the parboiled rice bran and defatted bran samples were stored in deep freezer condition at $-18{ }^{\circ} \mathrm{C}$ for further experiment.

\section{Chemical analysis of raw materials and final product}

Raw materials including wheat flour, full fatted and defatted rice bran samples and final products including seven types of bread samples were analyzed for moisture, ash, crude fat, crude fiber, crude protein, and crude carbohydrate according to AOAC (2000). The crude fiber, crude protein, and the fat content were subtracted from organic matter; the remainder accounted for carbohydrates: \% carbohydrate $=100 \bar{i}$ protein $(\%)+$ fat $(\%)+\operatorname{ash}(\%)$.

\section{Functional properties analysis of raw materials}

Functional properties of wheat flour and rice bran samples analyzed in terms of water absorption capacity, oil absorption capacity, bulk density and swelling capacity. The water absorption capacity and oil absorption capacity were determined according to the method of Sosulski et al. (1976). The bulk density and swelling capacity were determined according to the method described by Okaka and Potter (1977).

\section{Baking Process}

Composite Breads were baked in seven formulation (Table-1) according the modified method used by Begum et al. (2011).

Table 1. Formulation of composite breads

\begin{tabular}{lll}
\hline Bread & Product Code & Wheat flour : Rice bran \\
\hline A. Control bread & Control & $100: 00$ \\
B. $5 \%$ parboiled rice bran bread & P-5 & $95: 05$ \\
C. $10 \%$ parboiled rice bran bread & P-10 & $90: 10$ \\
D. $15 \%$ parboiled rice bran bread & P-15 & $85: 15$ \\
E. $5 \%$ defatted rice bran bread & D-5 & $95: 05$ \\
F. $10 \%$ defatted rice bran bread & D-10 & $90: 10$ \\
G. $15 \%$ defatted rice bran bread & D-15 & $85: 15$ \\
\hline
\end{tabular}




\section{Rheological property analysis of dough}

\section{Dough expansion}

The dough expansions were measured by the method described by Begum et al. (2011). According to the method all the ingredients were mixed to make dough, in which rice bran (2 types) were incorporated in different proportions $(0 \%, 5 \%, 10 \%$, and $15 \%)$. Then all the dough samples (A, B, C, D, E, and F) were accurately measured to make them identical in weight. Then these were placed in a $250 \mathrm{ml}$ measuring cylinder at $37^{\circ} \mathrm{C}$ and observed the expansion of dough with time.

\section{Physical analysis of bread samples with added rice bran}

Physical analyses were done on seven samples of the composite bread, including mass, volume, specific volume and density measurements. Bread sample masses were determined by using electronic analytical balance and volumes were determined by the displacement of mustard seeds, considering the principle of water displacement through the inflow-outflow technique. (ELdash et al., 1994). The specific volumes of breads were calculated according to AACC (2000) method based on the volume/mass ratio and the density is the reciprocal of specific volume.

\section{Organoleptic evaluation or sensory analysis}

The fresh samples (7 types) of composite bread was subjected to organoleptic evaluation by a panel (consist of 10 members), made up with faculties and students. The sensory characteristics such as aroma, crust color, crumb color, springiness, firmness, grain, taste, and overall acceptability were evaluated. Just before sensory test, bread loaves were cut into $2 \mathrm{~cm}$ thick slices and placed in plates. Each plate was given three digit code numbers before testing. The judges were provided with 9 point Hedonic scale and instructed to test (Organoleptic tests) the given coded sample and put the score (between 1 to 9 ) on the evaluation sheet as how much they like or dislike it on the point in the scale which best describe their feelings.

\section{Statistical analysis}

Statistical analyses were performed using the SPSS (version 20). Difference in proximate composition and sensory scores was detected using one-way analysis of variance (ANOVA). A significance level of $(<0.05)$ was used for the study. All the experiments were done with replication and analyzed with mean and standard deviation through Microsoft Excel 2013.

\section{Results and Discussion}

Physico-chemical, sensory evaluation and shelf life analysis of functional wheat bread supplemented with full fatted and defatted rice bran was carried out. Data generated during this investigation were tabulated and statistically analyzed. The results obtained are discussed under following suitable headings and subheadings.

\section{Proximate composition of raw materials}

Table 2 summarizes the proximate composition of wheat flour, full fatted rice bran and defatted rice bran. 
Table 2. Proximate composition of wheat flour, full fatted rice bran and defatted rice bran

\begin{tabular}{llll}
\hline Parameters & Wheat flour (\%) & Full fatted rice bran (\%) & Defatted rice bran (\%) \\
\hline Moisture & $11.85 \pm 0.05^{\mathrm{a}}$ & $11.51 \pm 0.11^{\mathrm{b}}$ & $9.32 \pm 0.15^{\mathrm{c}}$ \\
Ash & $1.55 \pm 0.35^{\mathrm{a}}$ & $9.98 \pm 0.15^{\mathrm{b}}$ & $11.88 \pm 0.23^{\mathrm{c}}$ \\
Crude Fat & $1.05 \pm 0.08^{\mathrm{a}}$ & $20.1 \pm 0.77^{\mathrm{b}}$ & $1.22 \pm 0.12^{\mathrm{a}}$ \\
Crude Fiber & $3.21 \pm 0.05^{\mathrm{a}}$ & $9.86 \pm 0.54^{\mathrm{b}}$ & $6.15 \pm 0.30^{\mathrm{c}}$ \\
Crude Protein & $19.5 \pm 0.25^{\mathrm{a}}$ & $24.58 \pm 0.38^{\mathrm{b}}$ & $20.78 \pm 0.26^{\mathrm{c}}$ \\
Crude Carbohydrates & 66.06 & 33.82 & 56.81 \\
& & & - \\
Gluten (\%) WB & $36.62 \pm 0.28$ & - & - \\
Gluten (\%) DB & $13.33 \pm 0.65$ & - &
\end{tabular}

Values are Mean \pm SD of three replicates. Different superscript in the same row indicates significant differences at $\mathrm{P}<0.05$

It was observed that both type of rice bran contained significantly higher $(\mathrm{p}<0.05)$ protein, fat, ash and fiber but lower moisture and crude carbohydrate content than procure wheat flour. In between two type rice bran full fatted rice bran contained higher protein, fat, fiber and moisture content than defatted bran. The results were in agreement with previously reported results by Sairam et al. (2011) and Quilez et al. (2013). The lower moisture content of rice bran justifies the suitability for long term storage without deterioration. Higher protein content of wheat flour is important for strong elastic dough which having high water absorptive capacity, excellent gas holding properties and will yield bread with good volume, grain and texture (Rodge et al., 2012).

Higher protein content of rice bran sample justifies the suitability of utilization of rice bran as a functional ingredient in formulation of food products to improve

Table 3. Functional properties analysis of raw materials nutritional characteristics. The fat content of full fatted rice bran was found to be $20.1 \%$. The ash content in rice bran was of $9.98 \%$. The higher ash content in rice bran contributed to its high mineral content. The crude fiber content of rice bran was of $9.86 \%$. It could be observed from the above table that rice bran did not contain any gluten but wheat flour contain $13.33 \%$ on dry weight basis $36.62 \%$ wet basis gluten. Gluten has the important property that when it is moistened and worked by mechanical action, it forms elastic dough. It does this by forming linkages between protein molecules. These linkages form a three dimensional structure which provides strength to the dough (Potter and Hotchkiss, 1996).

\section{Functional properties analysis of raw materials}

Table 3 shown the results of functional properties of wheat flour, defatted and full fatted rice bran.

\begin{tabular}{llll}
\hline Parameters & Wheat flour & Full fatted rice bran & Defatted rice bran \\
\hline Bulk density (g/ml) & $0.81 \pm 0.003^{\mathrm{c}}$ & $0.54 \pm 0.004^{\mathrm{a}}$ & $0.55 \pm 0.001^{\mathrm{b}}$ \\
Water absorption capacity $(\mathbf{m l} / \mathbf{g})$ & $2.5 \pm 0.1^{\mathrm{a}}$ & $2.8 \pm 0.1^{\mathrm{b}}$ & $4.4 \pm 0.1^{\mathrm{c}}$ \\
Oil absorption capacity $(\mathbf{m l} / \mathbf{g})$ & $1.8 \pm 0.1^{\mathrm{a}}$ & $1.9 \pm 0.1^{\mathrm{a}}$ & $2.0 \pm 0.1^{\mathrm{a}}$ \\
Swelling capacity $(\%)$ & $83.33 \pm 5.77^{\mathrm{a}}$ & $126.67 \pm 5.77^{\mathrm{b}}$ & $176.67 \pm 5.77^{\mathrm{c}}$ \\
\hline
\end{tabular}

Values are Mean \pm SD of three replicates. Different superscript in the same row indicates significant differences at $\mathrm{P}<0.05$ 
Results revealed that the bulk density of defatted rice bran is significantly different from wheat flour and full fatted rice bran. Highest bulk density $(0.81 \mathrm{~g} / \mathrm{ml})$ of wheat flour was due to the presence of smaller particles and the lowest bulk density $(0.54 \mathrm{~g} / \mathrm{ml})$ of full fatted rice bran was similar to the result reported by Rosniyana et al. (2007).

For full fatted rice bran water absorption, oil absorption and swelling capacity was found to be $2.8 \mathrm{ml} / \mathrm{g}, 1.9 \mathrm{ml} / \mathrm{g}$ and $126.67 \%$ respectively. Bhosale and Vijayalakshmi (2015) reported that water absorption capacity ranged from $2-3 \mathrm{ml} / \mathrm{g}$, whereas oil absorption ranged from 1.5 $2.5 \mathrm{ml} / \mathrm{g}$ for full fatted rice bran. For defatted rice bran water absorption, oil absorption and swelling capacity was found to be $4.4 \mathrm{ml} / \mathrm{g}, 2.0 \mathrm{ml} / \mathrm{g}$ and $176.67 \%$ respectively. Sairam, (2011) reported that bulk density, water absorption capacity and oil absorption capacity for laboratory defatted rice bran (LDRB) was $0.47 \mathrm{ml} / \mathrm{g}$, $2.10 \mathrm{ml} / \mathrm{g}$ and $1.80 \mathrm{ml} / \mathrm{g}$ respectively.

\section{Composite bread evaluation}

Composite bread made up with wheat flour, full fatted and defatted rice bran in different proportion were evaluated in terms of baking properties, dough expansion and sensory evaluation in order to ascertain the possibility of reducing wheat flour content in bread and replace them with locally available rice byproduct, rice bran.

\section{Expansion of dough}

The physical property of dough is a great concern in bread making process includes resistance to deformation, extensibility, elasticity and stickiness. Among the rheological properties of dough, expansion of dough with composite flour was carried out to observe how the expansion differ from different type and level of substitution. During proofing time, dough could expand due to gas production and gas retention. Dough expansion was measured in terms of dough volume increase at every 10 minutes interval (Begum et al., 2013). The expansion of dough with progressive time was illustrated in Fig: 1.

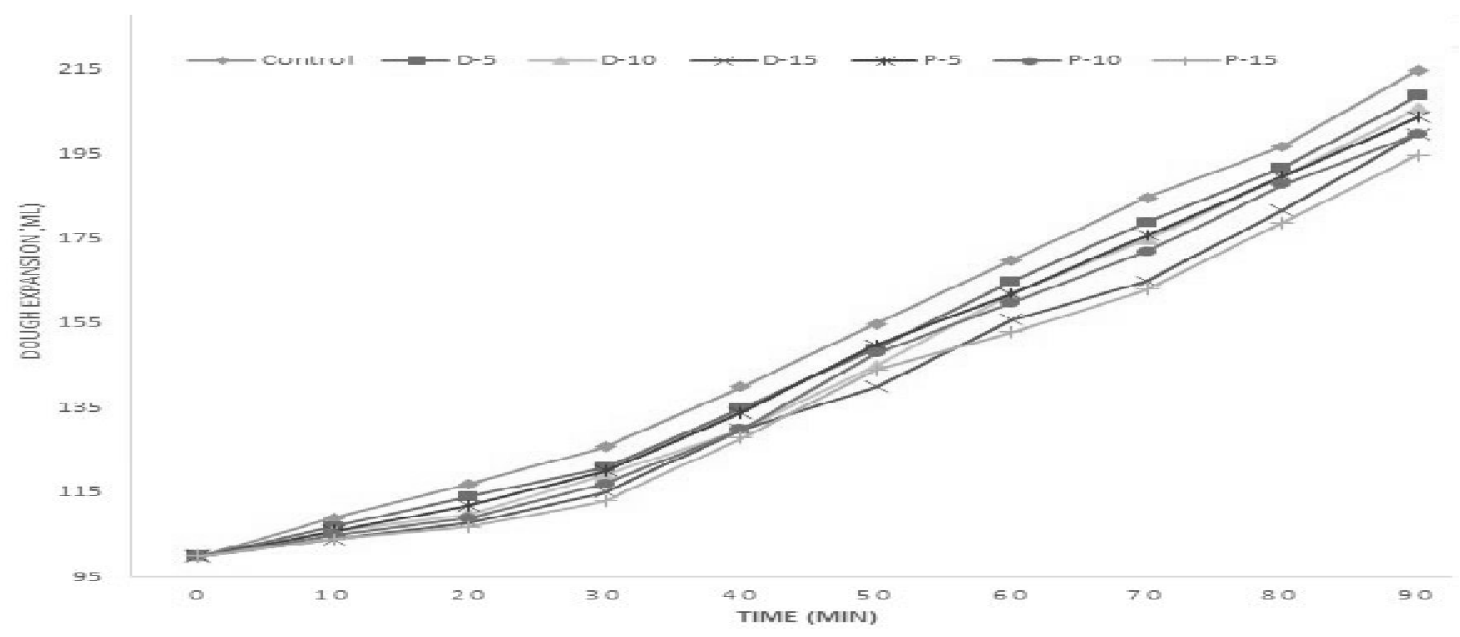

[Control: Wheat flour, (100\%); P-5: Wheat flour/Full fatted rice bran, (95:5); D-5: Wheat flour/Defatted rice bran, (95:5); P-10: Wheat flour/Full fatted rice bran, (90:10); D-10: Wheat flour/Defatted rice bran, (90:10); P-15: Wheat flour/Full fatted rice bran, (85:15); D-15: Wheat flour/Defatted rice bran, (85:15)].

Fig. 1. Expansion of dough containing various levels of full fatted and defatted rice bran

From the figure it was observed that wheat flour dough expanded much faster than any other combination. Rate of expansion of dough was decreased with the increase of both type of rice bran addition. Begum et al. (2013) 
also reported same that, wheat gluten of composite bread dough was diluted by composite flour which cannot retain gas. The decrease of dough expansion using $15 \%$ rice bran substitution seems higher as compared to lower substitution levels. The expansion of dough is almost identical for the both type of rice bran with $10 \%$ substitution.

\section{Baking properties of breads}

The result showed that specific volume of breads decreased progressively with increasing amount of rice bran flour in composite bread (Fig. 2).

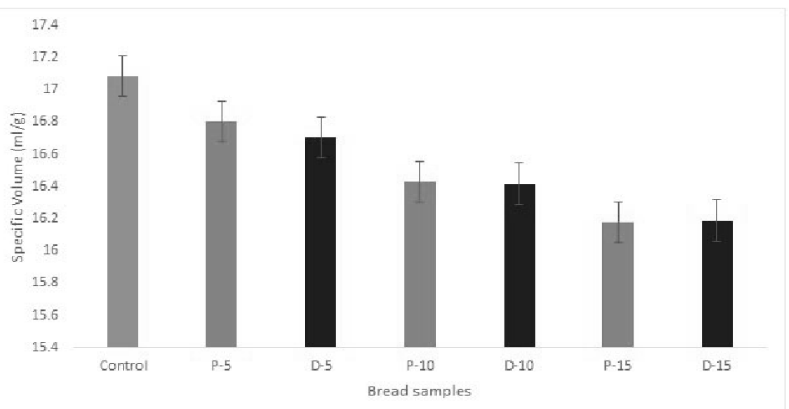

Fig. 2. Specific volume of composite flour bread containing wheat flour and rice bran

The specific volume control bread: Wheat Flour (100\%) is higher than any other composite breads. Maneju et al. (2011) also reported same that the specific volume decreased with increased incorporation of composite flour. This may be attributed to the higher level of gluten present in wheat flour compared to composite blends which could not be properly stretched by carbon dioxide $\left(\mathrm{CO}_{2}\right)$ gas during fermentation and proofing (Oladunmoye et al., 2010). It was also observed that the composite bread with similar proportion of rice bran but different in types with wheat flour (i.e. P-10 \& D-10) were not significantly different at 0.925 level from each other in terms of specific volume.

\section{Baking properties of composite breads Sensory analysis}

The acceptability of composite breads were determined in terms of sensory evaluation. The sensory scores of the wheat bread supplemented with full fatted and defatted rice bran in different proportion are shown in Table 4.

Table 4. Sensory evaluation score for composite breads

\begin{tabular}{|c|c|c|c|c|c|c|c|c|c|c|c|c|c|c|c|c|}
\hline \multirow{3}{*}{$\begin{array}{c}\text { Bread } \\
\text { Sample } \\
\text { Control }\end{array}$} & \multirow{2}{*}{\multicolumn{2}{|c|}{ Aroma }} & \multirow{2}{*}{\multicolumn{2}{|c|}{$\begin{array}{l}\text { Crust } \\
\text { Color }\end{array}$}} & \multirow{2}{*}{\multicolumn{2}{|c|}{$\begin{array}{l}\text { Crumb } \\
\text { Color }\end{array}$}} & \multirow{2}{*}{\multicolumn{2}{|c|}{ Springiness }} & \multirow{2}{*}{\multicolumn{2}{|c|}{ Firmness }} & \multirow{2}{*}{\multicolumn{2}{|c|}{ Grain }} & \multirow{2}{*}{\multicolumn{2}{|c|}{ Taste }} & \multicolumn{2}{|c|}{ Overall } \\
\hline & & & & & & & & & & & & & & & Acce & tability \\
\hline & 8.0 & 0.77 & 8 & 0.81 & 8.1 & 0.32 & 8.3 & 0.67 & 8 & 0.81 & 7.9 & 0.73 & 7.4 & 0.84 & 8 & 0.67 \\
\hline D-5 & 7.8 & 0.6 & 7.6 & 0.84 & 7.7 & 0.67 & 7.5 & 1.18 & 7.5 & 0.85 & 7.4 & 0.67 & 7.8 & 0.42 & 8 & 0.67 \\
\hline D-10 & 7.1 & 1.22 & 7.5 & 0.85 & 7.3 & 0.94 & 7.3 & 1.33 & 7.3 & 0.67 & 7 & 0.94 & 6.8 & 0.78 & 7.2 & 0.78 \\
\hline D-15 & 6.8 & 1.16 & 7.1 & 1.28 & 6.1 & 1.59 & 6.8 & 1.68 & 7.1 & 0.99 & 6.8 & 1.31 & 6.4 & 1.07 & 6.9 & 0.87 \\
\hline P-5 & 6.9 & 1.13 & 7.8 & 0.63 & 7.5 & 0.70 & 7.8 & 0.92 & 7.6 & 0.96 & 7.3 & 0.82 & 7.3 & 0.67 & 7.3 & 0.82 \\
\hline P-10 & 7.1 & 0.94 & 7.4 & 0.70 & 7.2 & 0.63 & 7.5 & 0.52 & 7.3 & 0.94 & 7 & 0.81 & 7.2 & 0.42 & 7.4 & 0.69 \\
\hline P-15 & 6.9 & 0.83 & 7.4 & 0.70 & 6.7 & 0.48 & 7.4 & 0.70 & 6.9 & 1.28 & 6.7 & 0.48 & 6.7 & 0.48 & 6.8 & 0.42 \\
\hline
\end{tabular}


Eight parameters were considered under organoleptic tests including aroma, crust color, crumb color, springiness, firmness, grain, taste, and overall acceptability. Overall acceptability was determined on the basis of quality scores obtained from the evaluation of aroma, color, springiness, firmness, grain and taste. It was observed that most of organoleptic characteristics also decreased with the increase of rice bran substitution level.

The panelists awarded higher scores for all of the sensory parameters of wheat bread than any other combination of composite bread (Table 5).

Table shows that ascending manner of rice bran substitution with wheat flour reduced the sensory quality of bread in descending manner. The panelist were scored between 8.00-8.99 when the liked the products very much. In accordance with that 7.00-7.99 scores were given they liked the products moderately and 6.00-6.99 scores were given when they liked the products slightly.

\section{Chemical composition of composite breads}

Chemical composition analysis were done for three out of seven bread sample, these were control bread, P-10 bread and D-10 bread. Among the composite breads, P10 and D-10 breads were selected for two reason. Firstly the overall acceptability score of these two samples were close to control bread and secondly based on a hypothesis that $10 \%$ substitution will give better nutritional quality in composite breads in contrast with $5 \%$ substitution for both types of rice bran.

Chemical composition was compute for moisture, ash, crude fat, crude protein, crude fiber, crude carbohydrate and energy value.

Results of the proximate composition of the bread samples are presented in Table 6. The moisture content in control sample of bread was found to be $22.89 \%$. The highest moisture content $29.33 \%$ was found in D-10 bread and the lowest moisture content $21.87 \%$ was found in P-10 bread. The increase in moisture might be due to the high water absorption by the rice bran and the reduced air entrapment, resulting in heavy dough. This was also reflected in the moisture content of bread loaves, with composite bread loaves giving higher moisture content than 100 per cent wheat flour bread (Michael et al., 2013). The reason behind this may be a higher insoluble dietetic fiber content gave by the rice bran which provides a high capacity to retain water (Biliaderis, 1992; Carroll, 1990).

The protein content in control bread was found to be $16.03 \%$. The protein content of bread samples was increased significantly from 16.03 to $17.26 \%$ with increased level of supplementation of defatted rice bran. The highest protein content $17.26 \%$ was found in D10 bread and the lowest protein content $13.28 \%$ was found in P-10 bread. The supplementation of wheat flour with rice bran holds the potential to uplift the nutritional profile of their food products with special reference to protein contents (Sekhon et al., 1997).

The fat content in control sample of bread was found to be $9.91 \%$. The fat content of D-10 bread samples was $5.98 \%$ and P-10 bread was slightly higher than D-10 bread. It was $7.73 \%$. The increase of fat content in the composite bread due to higher fat present in full fatted rice bran. The higher content of fat in the control or defatted bread may be due to the addition of fats and oils during production. In bread production, addition of fat imparts tenderness making it more palatable, assist in gas retention by making gluten more airtight. It also improves crumb texture and crust of loaf. External added fat during preparation of bread have plasticizing effects. The ash content in control sample of bread was found to be $1.08 \%$. The highest ash content $1.77 \%$ was found in P-10 bread. The ash content of D-10 bread was $1.60 \%$, which was smaller than P-10 bread but higher than control bread. The crude fiber content in control sample of bread was found to be $3.73 \%$. The highest crude fiber content $7.73 \%$ was found in P-10 sample of bread. The protein content of D-10 bread was 5.16\%, which was smaller than P-10 bread but higher than control bread. 
Higher fiber content of rice bran is the reason of high fiber in composite bread.

The carbohydrate contents of control bread sample were found to be $50.09 \%$. The carbohydrate contents decreased with $10 \%$ supplementation of defatted rice bran from 50.09 to $45.83 \%$. This is expected since there is very little carbohydrate left in rice bran after milling. The highest carbohydrate content $56.06 \%$ was found in P-10 sample of bread. This is expected since there is very little carbohydrate left in rice bran after milling. The results were in agreement with previously reported results for this kind product (Mumtaz et al., 2005).

Energy value of composite bread supplemented with full fatted and defatted rice bran

Energy value of a product is important to assess its impact on human health especially if it is marketed in

Table 5. Chemical composition of functional composite breads health sensitive consumer group. Therefore, efforts were made in present investigation to assess energy value of prepared functional composite bread supplemented with in different proportion of full fatted and defatted rice bran, on the basis of its proximate composition.

Energy value was determined by using values of crude protein, crude fat and total carbohydrate content of sample and considering that $1 \mathrm{~g}$ of protein yields $4 \mathrm{Kcal}$ energy, $1 \mathrm{~g}$ of fat yields 9 Kcal energy and $1 \mathrm{~g}$ carbohydrates yields $4 \mathrm{Kcal}$ energy. Total energy value is calculated by adding above three energy values which gives energy value per $100 \mathrm{~g}$ of sample. The data regarding the energy value of prepared functional composite bread supplemented with stabilized rice bran is presented in Table 5.

\begin{tabular}{llcc}
\hline Parameters & Control Bread & D-10 Bread & P-10 Bread \\
\hline Moisture & $22.89 \pm 1.55^{\mathrm{a}}$ & $29.33 \pm 0.35^{\mathrm{ab}}$ & $21.87 \pm 0.70^{\mathrm{b}}$ \\
Ash & $1.08 \pm 0.06^{\mathrm{a}}$ & $1.60 \pm 0.11^{\mathrm{a}}$ & $1.77 \pm 0.16^{\mathrm{a}}$ \\
Crude Fat & $9.91 \pm 0.20^{\mathrm{a}}$ & $5.98 \pm 0.02^{\mathrm{a}}$ & $7.02 \pm 0.26^{\mathrm{a}}$ \\
Crude Fiber & $3.73 \pm 0.07^{\mathrm{a}}$ & $5.16 \pm 0.08^{\mathrm{b}}$ & $7.73 \pm 0.12^{\mathrm{c}}$ \\
Crude Protein & $16.03 \pm 0.25^{\mathrm{a}}$ & $17.26 \pm 0.38^{\mathrm{b}}$ & $13.28 \pm 0.26^{\mathrm{c}}$ \\
Nitrogen Free Extract & 46.36 & 40.67 & 48.33 \\
Crude Carbohydrates & 50.09 & 45.83 & 56.06 \\
Total Energy & 353.67 & 306.18 & 340.54
\end{tabular}

Values are Mean $\pm \quad$ of three replicates. Different superscript in the same row indicates significant differences at $P<0.05$ [Control: Wheat flour, (100\%); P-10: Wheat flour/Full fatted rice bran, (90:10); D-10: Wheat flour/Defatted rice bran, $(90: 10)]$

The results shown that there was slight difference in energy value of functional wheat bread supplemented with rice bran. The control sample was having highest energy value of $353.67 \mathrm{kcal} / 100$ grams followed by P-10 bread sample (340.54 kcal/100 grams). The D-10 bread sample with the lowest value of energy (306.18 Kcal/100g) and highest protein content makes it suitable for specific group of population having disease or disability. The results were in agreement with previously reported results. (Malomo et al., 2011). composite bread with full fatted and defatted rice bran contained lower carbohydrate and fat but higher fiber which decrease energy value, 


\section{Conclusions}

Utilization of nutrient rich rice by product, rice bran as functional ingredients without being discarded was the main concern of this study. The study showed that both full fatted and defatted rice bran was high in fiber and protein in comparison with wheat flour. On the term of functional properties wheat flour exhibits lower value of water absorption capacity, oil absorption capacity and swelling power in relation with rice bran samples. In this study full fatted and defatted rice bran was supplemented with wheat flour in different proportion (i.e. $0 \%, 5 \%$, $10 \%$, and $15 \%$ ) to produce composite breads. The supplementation of rice bran samples in wheat flour for the preparation bread increased the protein and crude fiber than the wheat flour bread. It was also observed that specific volume of the composite breads decreases with the increase of rice bran proportions. The breads prepared with the addition of $10 \%$ of full fatted and defatted rice bran in wheat flour was found to be overall acceptable which was comparable to the control wheat flour bread. Hardness of composite breads was increased with increase in supplementation of rice bran in flour. There was no significant difference in springiness and crust color of control bread and composite bread. It could be finally concluded that the nutrient rich good quality composite bread can be prepared with incorporation of full fatted and defatted rice bran and the products was techno-economically feasible and can be commercially exploited.

\section{Acknowledgement}

The authors would like to acknowledge university research cell, MBSTU for financial support of the research project.

\section{References}

AACC 2000. Approved Method of American Association of Cereal Chemists. American Association of Cereal Chemistry, St. Paul., Minnesota, USA
AOAC 2000 Official methods of analysis of the Association of Official Analytical Chemists $17^{\text {th }}$ Edition AOAC International, Gaithersburg MD. Aransiola, 2014. ñMicrobiological, Nutritional, and Sensory Quality of Bread Produced from Wheat and Potato Flour Blends, ò International Journal of Food Science, vol. 2014:6. Article ID 671701.

Begum, R., Uddin, M. J., Rahman, M. A. and Islam, M. S. 2013. Comparative study on the development of maize flour based Composite bread. Journal of the Bangladesh Agricultural University, 11(1): 133 ï 139.

Biliaderis C.G. 1992. Structures and phase transitions of starch in food systems. Food Technology, 46: 98-109.

Shweta Bhosale and Vijayalakshmi D. 2015. Processing and Nutritional Composition of Rice Bran. Current Research in Nutrition and Food Science, Vol. 3(1), 74-80

Carroll L.E. 1990. Functional properties and applications of stabilized rice bran in bakery products. Food technology, 44(4): $74 і ̈ 77$.

El-Dash, A. A.; Mazzari, M. R.; Germani, R. Tecnologia de farinhas mistas: uso de farinha mista de trigo e milho na produção de pães. EMBRAPA-CTAA, v.1, p.42-88, 1994.

Houston, D F. 1972 Rice bran and polish. In Rice Chemistry and Technology. American Association of Cereal Chemists. St. Paul, MN. P p1-56.

Hu, G, Huang S, Cao S, and Ma Z 2009. Effect of enrichment with hemicellulose from rice bran on chemical and functional properties of bread. Food Chem. Article in press.

Kim JS. 2005. Radical scavenging capacity and antioxidant activity of the $\mathrm{E}$ vitamer fraction in rice bran. Journal of Food Science, 70(3):208ї 213.

Malomo S.A., Eleyinmi A.F. and Fashakin J.B. 2011. Chemical composition, rheological properties 
and bread making potentials of composite flours from breadfruit, breadnut and wheat. African Journal of Food Science, 5(7): 400 ï 410.

Maneju H., Udobi C.E. and Ndife J. 2011. Effect of added brewers dry grain on the physicochemical, microbial and sensory quality of wheat bread. American Journal of Food Nutrition, 1(1): 39-43

Mumtaz Shaheen, Faqir Muhammad Anjum, Masood Sadiq Butt, Allah Ditta Khan, Tahir Zahoor and Anwaar Ahmed 2005. Effect of rice bran supplementation on quality of bread. Pakistan Journal of Food Science, 15(2): 1-6.

Okaka JC, Potter NN 1979. Physicochemical and functional properties of cowpea powders processed to reduce beany flavour. J. Food Sci, 44: $1235-1240$

Oladunmoye O.O., Akinoso R. and Olapade A.A. 2010. Evaluation of Some Physico-Chemical Properties of Wheat, Cassava, Maize and Cowpea Flours for Bread Making. Journal of Food Quality, 33(6): 693- 708.

Potter N.N. and Hotchkiss H.J. 1996. Food Science. Fifth Edn. CBS Publishers and Distributors, New Delhi

Quereshi, A. A., Mo, H., Packer, L. And Peterson, D. M., 2000. Isolation and identification of novel tocotrienols from rice bran with hypocholesterolemic, antioxidant, and antitumor properties. J. of Agric. and Food Chem., 48(8): 3130-3140.

Quilez J., Zator M., Salas-Salvado J. and Alvarez L. 2013. Different stabilization treatments of rice bran added to wheat flour determine different properties in partially baked wheat bread. Italian Journal of Food Science, 25:222-228.

Rodge A.B., Sonkamble S.M., Salve R.V. and Syed I.H. 2012. Effect of Hydrocolloid (guar gum) Incorporation on the Quality Characteristics of
Bread. Journal of Food Process Technology, $3(2): 1-7$.

Rosniyana A., Hashifah M.A. and Shariffah Norin S.A. 2009. Nutritional content and storage stability of stabilised rice bran ï MR 220. Journal of Tropical Agriculture and Food Science, 37(2): $163 \mathrm{I} 170$.

Sairam, S., Gopala Krishna, A. G., \& Urooj, A. 2011. Physico-chemical characteristics of defatted rice bran and its utilization in a bakery product. Journal of Food Science and Technology, 48(4), $478 і ̈ 483$.

Sayre, R. N., Kahlon, T. S., Chow, I. F. I. And Chiu, I. M. M., 2007. Diet, Life Style and Risk of Coronary Heart Diseases, N. Engl. J. Med., 35(5): 1991-2000.

Sekhon K.S., Dhillon S.S., Singh N. and Singh B. 1997. Functional Suitability of Commercially Milled Rice Bran in India for Use in Different Food Products. Plant Foods for Human Nutrition, 50(2):127-140.

Sosulski FW, Humbert ES, Bui ES, Jones JI 1976. Functional properties of rapeseed flours, concentrates and isolates. J. Food Sci. 41: 13491351.

Wang, M \& Hettiarachchy, Navam \& Qi, M \& Burks, A \& TJ, Siebenmorgen. 1999. Preparation and Functional Properties of Rice Bran Protein Isolate. Journal of agricultural and food chemistry. 47: 411. 